\title{
ТЕОРІЯ ГЛОТОГЕНЕЗУ В ПУБЛІЦИСТИЧНОМУ ДИСКУРСІ ПАНАСА МИРНОГО Й ОЛЕСЯ ГОНЧАРА
}

Степаненко М. І. Теорія глотогенезу в публіцистичному дискурсі Панаса Мирного й Олеся Гончара.

У статті 3'ясовано проблему походження мови взагалі й історію постання української мови на базі праслов'янської мови за публіцистичною версією Панаса Мирного й Олеся Гончара, схарактеризовано спільні й відмінні положення теорії глотогенезу, запропонованої цими двома майстрами художнього слова.

Ключові слова: глотогенез, українська мова, спільнослов'янська мова, спільносхіднослов'янська мова, публіцистичний дискурс, Панас Мирний, Олесь Гончар. 
Степаненко Н. И. Теория глотогенезиса в публицистическом дискурсе Панаса Мирного и Олеся Гончара.

В статье рассматривается проблема происхождения языка вообще и история возникновения украинского языка на базе праславянского языка на основе публицистической версии Панаса Мирного и Олеся Гончара, охарактеризованы общие и отличительные положения теории глотогенезиса, предложенной этими двумя мастерами художественного слова.

Ключевые слова: глотогенезис, украинский язык, общеславянский язык, общевосточнославянский язык, публицистический дискурс, Панас Мирный, Олесь Гончар.

Stepanenko M. I. The theory of glottagenesis in publicistic discourse by Panas Myrnyi and Oles Honchar.

The paper clarified the problem of the origin of the language in general and the history of the Ukrainian language on the basis of the Slavonic language in particular according to the publicistic version of Panas Myrnyi and Oles Honchar. The author determined common and different issues of the glottagenesis theory suggested by these two masters of artistic expressions.

Key words: glottagenesis, the Ukrainian language, the common Slavonic language, the common East-Slavonic language, publicistic discourse, Panas Mirnyi, Oles Honchar.

Українська теорія глотогенезу зародилася давно. Вона представлена окремими іменами, цілими мовознавчими школами та напрямами. Цінні відомості щодо походження мови взагалі, місця української мови у слов'янському і світовому лінгвальному контексті зокрема знаходимо в публіцистичному доробкові багатьох письменників. Нашу увагу привернув своєю логікою, лінгвістичною вмотивованістю публіцистичний дискурс двох усесвітньо відомих постатей - Панаса Мирного та Олеся Гончара. Ці талановиті майстри художнього слова висловили цікаві лінгвістичні й соціолінгвістичні міркування про з'яву мови як найважливішого засобу комунікації, про зв'язок української мови з мовою спільнослов'янською, що постала на грунті індоєвропейської мови, й цим самим заперечили утрадиційнену в імперську добу концепцію про безпосередній зв'язок нашої мови 3 мовою спільносхіднослов'янською.

Лінгвістичні розмисли Панаса Мирного й Олеся Гончара мають чимало збіжностей, вони за багатьма засадничими положеннями узгоджуються 3 поглядами Степана Смаль-Стоцького, Михайла Грушевського, Івана Огієнка, Агатангела Кримського, Михайла Максимовича, і контрастують з погодінсько-соболевською гіпотезою, 3 культивованою в радянську епоху теорією про давньоруську мову як материнську колиску трьох братніх народів - українського, білоруського та російського.

Панас Мирний і Олесь Гончар стали не лише видатними 
письменниками, а й відомими мовознавцями, котрі залишили по собі глибокі за змістом лінгвістичні студії, що стосуються особливостей виникнення та розвитку мови як явища суспільного, їі філософської сутності, походження й основних етапів розвою української мови.

Своє кредо як мовознавець Панас Мирний висловив у численних листах, статтях та промовах: «Рідна мова», «Про мову», «Про життя Тараса Шевченка», «Полтава», «Відозва полтавців до киян 3 приводу святкування дня столітнього народження Т. Г. Шевченка», «Промова на могилі І. Котляревського». Поетичне гасло Тараса Шевченка: Hy щ⿻о б, здавалося, слова... Слова та голос - більш нічого. А серце б'єтьсяожсив, Як їx почує!.. - змусило Панаса Яковича задуматися над питанням «про людську річ взагалі яко вираз наших думок, почувань i про мову народну - особисто яко вираз народної душі, народного світогляду» [4, с. 270]. Цю проблему він вкладає в русло відомої вигукової гіпотези походження мови, за якою фундаментом творення мови послужили звуки, що постійно супроводжували діяльність первісної людини. За беззмістовним сполученням звуків поступово закріплювалася певна інформація, позаяк вони оречевлювали ту або ту постійну чи тимчасову роботу. Видів праці було багато, тому й з'явилася потреба називати кожен iз різновидів трудового процесу людини окремою лексемою (нагадаємо принагідно, що теорію трудових вигуків у XIX ст. обгрунтували вчені Л. Нуаре і К. Бюхер). Інтер'єктивну теорію, яку сучасні вчені-лінгвісти вважають одним із паростків наукової думки, Панас Мирний інтерпретує так: «Річ людська взагалі виникла 3 того враження, що відбивалося у людській душі від усього того, що людям доводилося або самим бачити, або від других чути про те, що вони бачили. Різні враження збентежували людську душу - то іï лякала або милувала сама природа 3 iï страшними проявами або навдивовижу хорошими постановами, яких не змалює самий митецький маляр, то викликали усякі почування, відносини своїх родичів або близьких сусід. Усі ті враження треба було виявити різними зразками або вигуками; треба було змовитися, що той або другий зразок чи вигук означає те чи інше враження, треба було ті зразки чи вигуки запам'ятати. Таким побитом складалася людська річ, перелилося бачене і чуте в зразкивигуки, в те, що ми називаємо тепер словами» [4, с. 270]. Свою теорію він будує на загальновідомому положенні про історичний поступовий розвиток мови, про те, що їі збагачує і вдосконалює кожне покоління людей: «...ми разом з словами набираємося і розуму, набуваємо чужих думок, навчаємося самі думати і ті думки викладати словами. Наші діти, у свою чергу, додають до здобутого від нас скарбу мови своїх вимовів 
того, що їм за свого життя довелося навчитися, передумати, пережити» [4, с. 278]. Мова, висновує Панас Мирний, «кожним новим поколінням все більше та більше шириться - зростає» [Там само].

Цікавила письменника і така проблема, як «чи одна мова була в перших людей, чи у кожного була своя мова» [4, с. 271]. Розв’язати він їі не зміг, чого й варт було ждати, бо й сьогодні в науці це питання ще не дістало вичерпного витлумачення. Панас Мирний зосереджує погляд на тому, що «історія вже застала людей з різними мовами» і це «не тільки не зашкодило людям, а ще послугувало на користь їх розвою» [Там само]. I немає у світі такої сили, яка звела б докупи всі мови, тому що вони залишаться назавжди найприкметнішою характеристикою будьякої етнічної спільності. Намагання злити всіх людей в одне мовне море справа «чудна»: «Чудне то бажання. Це все однаково як сказати, як добре б було, якби всі люди їли однакову їжу, носили однакову одежу. Чи не заваде шлункові негра той жир, що потрібляє його який-небудь лапланець? Або буде хороша негрові та тепла з линтваря одежа, що носе ii і зиму й літо ескімос?» [Там само]. Ці запитання, зрозуміло, риторичні.

Особливе місце в лінгвістичному доробкові Панаса Мирного займає стаття «Рідна мова», у якій подано оригінальне поетичне визначення мови: «Найбільше і найдорожче добро в кожного народу - це його мова, ота жива схованка людського духу, його багата скарбниця, в яку народ складає і своє давнє життя, і свої сподіванки, розум, дослід, почування» [4, с. 187]. Воно не має жодного зайвого слова, наповнене глибоким філософським і лінгвістичним змістом, позначене художньою довершеністю. Щоб переконатися в істинності цієї тези, варто зіставити розглядувану дефініцію 3 науково виваженим, окласичненим трактуванням мови, хоч би з таким: «Мова - це особлива, специфічна, історично змінна знакова система, що служить найважливішим засобом спілкування, засобом формування i вираження думок та почуттів». Спробуємо розкрити зміст найістотніших його ознак. Перша ознака: мову потрактовано особливою знаковою системою тому, що поряд із нею існують й інші системи знаків: знаки-ознаки, знаки-сигнали, знакисимволи. Панас Мирний називає мову найбільшим i найдорожчим добром народу, маючи на увазі, що, крім неї, існують інші етнічні цінності, без яких, як і без мови, суспільству не обійтися. Друга ознака: специфічність мови полягає в тому, що вона властива тільки людині, народові. Третя ознака: мова - явище історичне, вона перебуває в постійному русі та розвитку. Письменник номінує цю важливу характеристику одним словом-прикметником жива, що реалізує значення «неперервна зміна». Четверта ознака: мова $є$ засобом 
спілкування (комунікативна функція), формування і вираження думок (мислеоформлювальна функція) та почуттів (естетична функція). У дефініції цим функціям надано особливого звучання: «у мову народ складає своє життя» (комунікативна функція), «почування» (естетична функція). Якщо ми заглибимося в природу мови й вичленуємо інші властиві їй функції, які прямо пов'язані з проаналізованими вище трьома основними, то і їхню присутність віднайдемо в тому без перебільшення енциклопедичному визначенні, яке вміщене у статті «Рідна мова»: акумулятивна (функція нагромаджувальна) = мова - «жива схованка», «багата скарбниця»; аксеологічна (функція оцінна) = мова - «найбільше і найдорожче добро»; конативна (функція засвоєння) = у мову народ складає свій «дослід»; функція передачі національної самосвідомості = мова $\epsilon$ добром кожного народу. Компаративний аналіз можна поглиблювати й поглиблювати, однак і поданих відомостей достатньо, щоб пересвідчитися в повноті й точності поетичної кваліфікації мови за Панасом Мирним. Здійснюваний опис буде не повним, якщо поза увагою залишити ще один досить суттєвий момент: мова - явище матеріальне. Під мовною матерією, одиницею якої виступає звук, письменник розуміє «людський дух», який дає мові життя, утримує іï в часі, просторі, уможливлює іiі рух.

Уважаючи українську мову окремим «язиком», а не діалектом чи говором «общерусской речи», убачаючи їі майбутнє в тому, що вона не буде «закинута у глухі села», не стане «говіркою задля хатнього обійстя», а служитиме потребі «культурного життя та широкого письменства» [4, с. 295] і займе місце в одному ряду з передовими мовами світу, письменник указує на шляхи іiі розвитку. Ними є, поперше, народнорозмовна стихія, по-друге, мовна практика митців художнього слова, по-третє, переклади. Панас Мирний, як і Іван НечуйЛевицький, був глибоко переконаний, що основне живильне джерело української мови - сільська мова. Про це йдеться в листі до Михайла Коцюбинського: «... [селянське життя] виробило нашу живу мову, що давно заснувалося і ще й досі дає свої живі оригінальні зразки своїх типів, а не общечоловіків...» [4, с. 498]. Видобуті з народних вуст мовні скарби зазнавали істотних змін у малій і великій прозі письменника. «Треба й це ще добре гладити та виправляти, - наголошував він, - щоб як читати, то річ, як чистий струмочок, лилася сама собою» [4, с. 438]. Досить помірковано, навіть холодно, митець ставився до «кування» нових слів, яке було на той час модним, до «Тредьяковського вінегрету» [4, с. 468]. У зв'язку з цим Панас Мирний висловився в листі до Цезаря Білиловського: «По правді скажу: не подобались мені всі ті 
[вірші. - М.С.], де уживаються нові слова, виковані з чужих мов. Невже своїх не достає? Невже не можна краще писати... поки того розуму добереш - то й голову затуманиш; або поки вимовиш - то й язика поламаєш!» [4, с. 430].

Панас Рудченко в листах до різних адресатів постійно наголошує на тому, що потужним джерелом розвою української літературної мови $\epsilon$ також творчість славетних майстрів рідного слова, які мають «високо піднімати вгору свою рідну мову» [4, с. 273], оздоблювати, шліфувати ії. Він найвище поціновує літературно-мовну практику Івана Котляревського й Тараса Шевченка. «Кладучи своє слово» на могилу Котляревського, він говорить: «Твої невмирущі твори найбільш всього уславили Тебе на всю широку Україну, котру Ти за свого життя так щиро кохав і задля її занедбаної мови так багато зробив...» [4, с. 269]. Феномен мови творів Великого Кобзаря, за Панасом Мирним, полягає в тому, що «огненне слово його наскрізь проймало серце», «всі дивувалися красі та силі тії простої мови, якою Шевченко виливав свої вірші. Увесь світ став прислухатися до його мови» [4, с. 275]. Письменник звертається до своїх сучасників - Михайла Коцюбинського, Михайла Старицького, Івана Нечуя-Левицького, Сергія Єфремова - $з$ проханням і наказом, щоб вони ненастанно плекали материнську мову, збагачували «нашу не дуже-то родючу ниву своїми коштовними творами» [3, с. 499], докладаючи всіх зусиль, аби «з простої речі» виробилася дзвінка та співуча мова, «немовби то великий музика на чудовій скрипці грає і своєю грою вражає душу і серце!» [4, с. 516], щоб рідне слово не було «облямовкою чужого життя» [4, с. 499]. Отже, він закликає побратимів по перу писати «чистою, як кринична вода, народною мовою» [4, с. 431] і запевняє їх, що «3 того засіву будуть колись великі жнива задля нашого рідного краю» [Там само].

Некваліфікований переклад, на думку Панаса Мирного, підриває престиж мови, викликає небажане негативне ставлення до нашої літератури, яка міцно стає на ноги. Сам письменник подав приклад того, як можна через переклад збагачувати українську мову, уводити iï у слов'янський i світовий культурний простір. До перекладачів мають ставитися особливі вимоги, бо трапляються, а жаль, випадки, коли зі світової класики робиться «посміховище задля наших ворогів» [4, с. 433]. Панас Якович переклав «Думу про Гайавату» Г. Лонгфелло, «Короля Ліра» У. Шекспіра, «Думу про військо Ігореве». Він радив іншим талановитим майстрам слова братися за цю вкрай відповідальну, але необхідну і важливу справу. Уважне вивчення публіцистичних розвідок, епістолярію Панаса 
Мирного дає змогу чітко окреслити його погляди на проблему походження української мови й основних етапів ії становлення. Коріння рідної мови письменник пов'язує 3 давньою епохою, а не з XIV чи XIII століттям, тобто його лінгвістична версія не збігаються з академічною позицією про Київську Русь як материнську колиску російського, українського та білоруського народів і спільну для східних слов'ян давньоруську мову. Українська мова, наголошено у «Відозві полтавців до киян 3 приводу святкування дня столітнього народження Т.Г. Шевченка», ще за «великокняжих часів вільно ширилась й розросталася, а за козацькі часи була зброєю, якою українська людність боронила свою культуру. Це ж стародавня матірня руська мова, винесена на світ божий з глибоких джерел народного творчого духу, викувана під вражінням просторів своєї країни, свого неба і сонця, землі, води і повітря» [4, с. 295]. Але після того часу, коли доля сполучила Стару i Нову Русь, Московська Русь піднеслася високо вгору і стала називатися Великою Руссю, а Стара Русь-Україна, яка почала іменуватися Руссю Малою, хилилася донизу. Хилилася донизу і їі мова, яку Панас Мирний назвав «найстарішою руською мовою» [Там само]. Ця мова самобутньо заяскравіла вже у творах «безвісних літописців України-Русі та невідомого співця «Слова о полку Ігоревім» [4, с. 294]. Нову багатогранну перспективу нашому слову відкрив Тарас Шевченко, вивівши його на «просторий шлях всесвітнього поступу», проклавши ним «широку стежку до народного відродження» і сполучивши «давню славу свого краю з новою і сучасною» [4, с. 295-296].

У дослідженнях Панаса Мирного історію української літературної мови поділено на два періоди: староукраїнський 3 його княжою та козачою добою і новоукраїнський. В останньому періоді він виокремлює добу Котляревського, який «перший по талану» завів у літературну мову наше просте слово» [4, с. 353], добу Квітки, котрий пішов за Котляревським і зробив вагомий крок, бо в кожному його творі «уже не чується глухого реготу над мужичою мовою, який чується в Котляревського, не видно уже варнякання» [Там само], i, нарешті, добу Шевченка, чиї ідеї «заполонили < . .> тисячі прихильників» [Там само].

Лінгвістичні та соціолінгвістичні сюжети публіцистичного дискурсу Олеся Гончара, як уже було наголошено, споріднені 3 мовознавчими сюжетами публіцистики Панаса Мирного, подеколи доповнюють їх, а подеколи постають іншими - новими гранями. У щоденниках знайшла повне висвітлення теорія виникнення мови. Письменник не визнавав загальноприйнятої концепції еволюції («мавпячої теорії»), вважав, що вона «зручна для тих, хто мало думає 
$<\ldots>$ Чому така стабільність людських рас? Упродовж тисячоліть не помічено анінайменших змін <..> I чому саме так розселилися? Свропа - білі, Азія - жовті, Африка - чорні. Наче хтось вищий поділив планету - як між дітьми» [2, т. 2, с. 288]. Надалі вказуватимемо лише дату щоденникового запису.

Гончар критикує вульгарне примітивне безбожництво, яке прикривалося Дарвіновим ученням (сам він, як відомо, протестував проти цього). «Глянь-бо: світ який досконалий! - зафіксовано в щоденнику 3 травня 1995. - Чому той барвінок цвіте синеньким (серед зелені), а вишня красується білим? Звідки беззахисний їжачок утямив, що для захисту йому треба огорнутись голками? Ластівка в'ється у високості, білка скаче по верховіттю... В цьому - безмір досконалості. В цьому - присутність провидіння, найвищої загадкової сили». «А хіба ж не загадка: чому всі живі створіння на планеті мають єдиний генетичний код? - читаємо ще один запис. - Жирафа й квітка троянди, людина й бактерія - об' єднані всі вони спільним кодом. Це наводить на думку, що посів життя на планеті був завершений зі сторони, десь, звідкись. Мільярди років тому кинуто було з космосу жменю бактерій у земний «первісний бульйон». До речі, найстарішими на планеті є синьо-зелені водорості. Чи не вони жили в первісному океані? Для мене звучить переконливо, що життя посіяно. Але хто ж був сівач?» [16 серпня 1983]. На глибоке переконання Олеся Терентійовича, колективно твориться й мова. У цьому великому процесові беруть участь «і сивий людський досвід, і закохана юність, і розбурхана дитяча уява» [1, с. 302].

У щоденниках Гончара добре виписана проблема походження української мови. Ще 1969 року занотовано таке: «Відомий учений Алексєєв, досліджуючи ост[анні] археологічні дані, в главі «Укр[аїнські] черепи» доводить, що в українців зовсім нема монголоїдних рис. Відносить їх до середньоморськодорійської раси» [11 грудня 1969]. Цей авторитетний науковець оперував археологічними фактами, які дали йому підстави констатувати, що нинішні українці та їхні предки VIII-XII ст. - одні й ті самі люди, що «сучасні українці не відрізняються < ..> від середньовічних племінних груп, які увійшли до їхнього складу». Працю видано в Москві, у нас «такі речі не пройшли б, було б вам, тов. Алексєєв» [Там само], звертається до нього Гончар. У діаріуші Олеся Гончара йдеться і про український генотип, про українську природу жінок - полтавок, степовичок, у яких немає нічого від рязанських чи від болотної чуді, запевняє, що ми окрема нація, що «в нас своя, південна, кров, нічого спільного з рязанським чи фінським генотипом; значно ближчі до нас серби та інші балканські слов'яни, i 
навіть молдавани, угорці» [18 липня 1992]. Очевидно, письменник був знайомий із працями Степана Смаль-Стоцького та Івана Огієнка, які, аналізуючи історичні зв'язки української мови з іншими спорідненими мовами, доводили, що вона багатьма своїми характеристиками наближається не до російської мови, як це пропагують російські вчені (тільки з політичних міркувань уподібнюють українську мову до мови російської), а до сербської, бо ж українець, що не знає російської мови, легше розуміється із сербом, аніж із росіянином. Цікавим і цінним є ще один запис, який безпосередньо стосується українського глотогенезу розмова історика Ключевського зі своїми студентами, яку зафіксував «якийсь Гордов»: «Несколько слов об украинцах», «Возрождение», «Париж», кн. 115, 1961, стр. 150: «Уявіть собі, що Київ не був би взятий і зруйнований татарами. Він би залишався столицею великої руської держави. А Москва б залишалась напівфінським затишним містечком. Тож офіuійною мовою держави стала б не суміш старослов'янської та фінської мов, а слов'яно-украӥнська! I український письменник Гоголь не мусів би писати російською, а Пушкін писав би українською» [24 червня 1993]. 3 роздумами Ключевського перегукуються такі висловлені в щоденниках розмірковування Олеся Гончара: «... походив Бунін, як свідчать біографи, 3 «литовської» (тобто білоруської або української) шляхти - Буньковський, і в родині його називали Яном $<\ldots>$ Росіяни дуже не люблять, коли їм нагадують такі речі. Що й Достоєвський родом татаро-литовець, і Грибоєдов насправді був Gzubowski (з повстанської польської родини), не кажучи вже про Гоголя, який для всіх «великоросів» був стовідсотковим «хохлом». То що ж тоді залишається пильнувачам імперської расової чистоти? Африканець - Пушкін?» [14 липня 1992]. Думку Ключевського Гончар називає блискучою фантазією. Ми ж відносимо цю думку-фантазію до так званих «сенсаційних» теорій українського глотогенезу (див. про це: [5, с. 11-42]) і ставимо в один ряд із «Велесовою книгою»-своєрідним літописом життя наших пращурів, героїчним епосом України-Руси, 3 концепцією польського й російського сходознавця Михайла Красуського про українську мову як ровесницю санскриту давньоіндійську літературну мову, як найстарішу в Європі мову, як давнішу не тільки за всі слов'янські мови, а й за грецьку та латинську.

Олесь Гончар свідомий того, що вище знання, вище пізнання треба шукати не в наукових лабораторіях, а в глибинах санскриту, бо «там може виявитись не лише спресований у віках людський досвід, а може, досвід іще чийсь» [12 червня 1984], бо індійська цивілізація має багато спільного 3 європейською, i «в нашій мові багато 
санскритських коренів, - дослідити б: чому?» [24 червня 1984]. Він певен, що наукова правда про походження української мови в недалекому майбутньому обов'язково восторжествує.

Погляд Гончара на першопочатки української мови, на те, «хто вони, люди найдавніших, праукраїнських племен?» [Там само], знаходимо і в записах, датованих 1975 та 1995 роками. У нотатці від 11 травня 1995 року Олесь Терентійович хоче пояснити американському президентові Біллу Клінтонові, який прибув із дружиною до Києва, що таке Росія, яку інший Президент США назвав «імперією зла»: «Росія - це дочка України, але дочка загребуща, агресивна, 3 домішкою дикої азіатчини». Україна ж триста літ була іï донором, «живила iї своєю кров’ю, віддавала їй свої таланти» [11 травня 1995]. Отже, і російська мова, за автором щоденників, - дочка української. Це не відкриття, а творча інтерпретація позиції Михайла Грушевського, який, бачачи спільне між українцями, білорусами й росіянами та специфічне відособленість їхніх племен, твердив, що етнічні українські землі ще за часів Київської Русі заселяли українці, а «етнографічна й історична близькість народності української до великоруської не повинна служити причиною до їх перемішувань - вони жили своїм життям поза своїми історичними стичностями і стрічами».

У запису від 2 листопада 1975 року письменник згадує про смерть друга України великого англійського історика Арнольда Тойнбі, автора 12-томної історії людства, наголошуючи, що той, як і наш великий історик Грушевський, уважав Україну спадкоємницею Київської Русі, «був певен, що царистська історіографія принижує насамперед рос[ійський] народ, бо позбавляє його власної історії, іiі витоків (прив'язуючи його штучно до київ[ського] престолу)». Не погоджується Олесь Гончар із тверджееням про те, що Україна $є$ центром Свропи (і не лише географічним). Він вважає це перебільшенням, яке тільки лестить нашому національному самолюбству. Центр Свропи там, «де Гутенберг спорудив першу друкарню, де творили Мікеланджело і Рембрандт, де виник перший парламент, і з'явився перший роман «Дон Кіхот», і звідки йшли перші Магелланові кораблі відкривати Світовий океан... I це ж тоді, коли біля нашої святої Софії кози паслися в бур'янах після татарських погромів і лише ледь-ледь сходила над Січчю зоря майбутньої свободи < ..> Нi, не треба прикрашувати нам свою історію» [8 травня 1991]. Не треба вдаватися й до інших крайнощів - ревізувати свою історію, применшувати власну гідність, переінакшувати минувшину, у чому нас пересвідчує знову ж таки автор «Щоденників», бо свята Софія - це наша історія, і наші кози паслися там [а не сусідські. 
- М. С.]. Жаль, що Київську Русь поруйнувала татарська навала. Духом своїм ми належимо Європі, наголошує Олесь Терентійович, i, може, справді «ключ від майбутніх проблем континенту лежить у нашій українській кишені <..> будемо вірити» [Там само]. Вірити варт і в те, що Бог «відкрив нам дорогу до європейського дому! Бо тільки там Україна знайде свій порятунок, там - наша доля!..» [Там само].

Сучасне мовознавство прийняло версії Панаса Мирного й Олеся Гончара про коріння, походження української мови, зокрема ту, що наша мова, як i інші слов'янські, бере свій початок із мови спільнослов'янської або іiї сліди треба шукати в XI столітті, а не в XIV, оскільки в цей час вона мала своє самобутнє, цілком самодостатнє обличчя, вирізнялася 3-поміж інших генетично споріднених мов власним фонетичним, лексичним, граматичним, стилістичним ладом.

\section{Література}

1. Гончар О. Цвіт слова народного / О. Гончар // Письменницькі роздуми : літературно-критичні статті. - К., 1980. - С. 296-303.

2. Гончар О. Щоденники : у 3-х т. / О. Гончар ; упоряд., підготов. текстів, іл. матеріалу В. Д. Гончар. - К. : Веселка, 2002-2004. - Т. 1: (1943-1967). - 455 с. ; т. 2: (1968-1983). -2003. - 607 с. ; т. 3: (1984-1995). - 2004. - 606 c.

3. Квітка-Основ'яненко Г. Ф. Твори : у 6-и т. / Г. Ф. Квітка-Основ'яненко. - К. : Держлітвидав, 1957. - Т. 4 : Оповідання. Пан Халявський. -419 с.

4. Мирний Панас (П. Я. Рудченко) Зібрання творів : у 7-и т. / Панас Мирний. - К. : Наукова думка, 1971. - Т. 7 : Поезія. Публіцистика. Епістолярій. - 663 с.

5. Степаненко М. Рідне українське слово / М. І. Степаненко. - Полтава : АCMI, 2005. $-391 \mathrm{c}$.

Стаття надійшла до редакції 11.11.2013 p. 